\title{
Looking ahead
}

\section{The risk of neurologic complications due to COVID-19}

Carlos A. Pérez, MD

Neurology: Clinical Practice August 2020 vol. 10 no. 4 371-374 doi:10.1212/CPJ.0000000000000836

Correspondence

Dr. Pérez

Carlos.A.Perez@uth.tmc.edu

\section{Abstract}

The rapid spread of Coronavirus disease 2019 (COVID-19) caused by severe acute respiratory syndrome coronavirus 2 has become a public health emergency of international concern. The outbreak was characterized as a pandemic by the World Health Organization (WHO) in March 2020. The most characteristic symptom of patients with COVID-19 is respiratory distress. Some patients may also show neurologic signs and symptoms ranging from headache, nausea, vomiting, and confusion to anosmia, ageusia, encephalitis, and stroke. Coronaviruses are known pathogens with neuroinvasive potential. There is increasing evidence that coronavirus infections are not always confined to the respiratory tract. CNS involvement can occur in susceptible individuals and may contribute overall morbidity and mortality in the acute setting. In addition, postinfectious, immune-mediated complications in the convalescent period are possible. Awareness and recognition of neurologic manifestations is essential to guide therapeutic decision-making because the current outbreak continues to unfold.

\section{Virology and taxonomy}

Severe acute respiratory syndrome coronavirus 2 (SARS-CoV-2) belongs to the broad family of coronaviruses. ${ }^{1,2}$ It is an enveloped, positive sense, single-stranded RNA (+ssRNA) virus with a diameter of approximately $60-140 \mathrm{~nm} .^{3}$ The viral envelope consists of a lipid bilayer with 4 structural proteins known as S (spike), E (envelope), $\mathrm{M}$ (membrane), and $\mathrm{N}$ (nucleocapsid). ${ }^{2}$ Interaction between the spike protein and host cell receptor is essential for virulence and infectivity. ${ }^{4}$ Similar to severe acute respiratory syndrome coronavirus (SARS-CoV) — the causative agent of the SARS global outbreak in 2003-and Middle East respiratory syndrome coronavirus (MERS-CoV), SARS-CoV-2 is a member of the genus Betacoronavirus $(\beta \mathrm{CoV}){ }^{5}$

Genomic sequence analyses of SARS-CoV-2 have shown $82 \%$ identity with SARS-CoV 6 and an estimated mutation rate of approximately $10^{-3}$ substitutions per site per year, ${ }^{7}$ similar to other ssRNA viruses. Although a mutation in the spike protein is the likely culprit for the recent introduction of SARS-CoV-2 into the human population, sequence variation among various isolates remains low, and a few mutation "hot spots" have now been described. ${ }^{8}$ These advances should help facilitate vaccine design, clinical monitoring, and management of Coronavirus disease 2019 (COVID-19).

The neuroinvasive nature of human coronaviruses has been previously described, and neurotoxicity may occur because of indirect, direct, and postinfectious complications. ${ }^{9}$

\section{MORE ONLINE}

\section{COVID-19 Resources}

For the latest articles, invited commentaries, and blogs from physicians around the world NPub.org/COVID 19 


\section{Indirect neurologic complications}

Coronaviruses generally cause respiratory and enteric diseases in animals and humans. ${ }^{2}$ In a report of 44,500 confirmed COVID-19 patients by the Chinese Center for Disease Control and Prevention, $81 \%$ of cases consisted of mild pneumonia, $14 \%$ were characterized by more severe diseases, including dyspnea and hypoxia, and 5\% had respiratory failure, shock, or multiorgan dysfunction. ${ }^{10}$ Sepsis, heart failure, and septic shock are among the most frequently reported systemic complications of COVID-19, ${ }^{11}$ and extrapulmonary involvement of SARS-CoV-2 may induce neurologic signs and symptoms.

A recent report of 99 COVID-19 patients in Wuhan, China, described the presence of neurologic manifestations, including confusion (9\%) and headache (8\%). In a different report of 214 COVID-19 patients, $36.4 \%$ were found to have neurologic manifestations at presentation, including headache, nausea, vomiting, impaired consciousness, ataxia, acute cerebrovascular disease, and seizures. ${ }^{12}$ Secondary neurologic manifestations of COVID-19 are believed to result from the widespread dysregulation of homeostasis due to pulmonary, renal, hepatic, and cardiovascular injuries. ${ }^{13}$ In addition, direct and indirect cardiotoxicities secondary to excessive systemic proinflammatory stimulation (cytokine storm), hypercoagulability, and direct myocardial invasion are associated with myocardial infarction, heart failure, and arrhythmias, which are the important risk factors for stroke. ${ }^{11}$

\section{Direct neurologic complications}

In previous SARS-CoV infections, postmortem studies have reported the presence of viral RNA within brain tissue of the affected individuals. ${ }^{14}$ Acutely ill patients with SARS-CoV have also demonstrated the presence of the virus in the CSF. ${ }^{13}$ Experimental animal studies using transgenic mice have further revealed that after the intranasal administration of SARS-CoV, the virus can enter the brain, and thereafter, it may spread to specific areas of the CNS, including the thalamus and the brainstem. ${ }^{15}$ In addition, cases of human coronavirus $(\mathrm{HCoV})$-related meningitis, encephalitis, and acute flaccid paralysis have been reported over the years. ${ }^{9}$

Similar to SARS-CoV, SARS-CoV-2 seems to enter human host cells by binding to the angiotensin-converting enzyme 2 (ACE2) receptor on the surface of epithelial cells in the lung, intestine, kidney, and blood vessels. ${ }^{13,16}$ The exact mechanism by which SARS-CoV enters the CNS remains unclear but may involve disruption of the nasal epithelium and entry via the olfactory bulb with subsequent retrograde transsynaptic spread. ${ }^{9}$ Interestingly, evidence of neuronal expression of the ACE2 receptor has recently emerged from human protein databases, ${ }^{17}$ but a clear role for this receptor in $\mathrm{HCoV}$ entry into the CNS has not been established. A recent report describing the ability of $\mathrm{HCoV}$ to induce direct neuronal injury within brainstem cardiorespiratory centers in experimental animal models ${ }^{2}$ has raised concern that SARSCoV-2 may be partially responsible for the acute respiratory failure reported in patients with COVID-19.

In addition, an association between COVID-19 and early onset olfactory and gustatory dysfunction has been reported recently. ${ }^{18}$ The American Academy of Otolaryngology proposed that anosmia, hyposmia, and dysgeusia should be added to the list of COVID-19 screening symptoms and urged precautionary isolation for individuals with these symptoms, even in the absence of respiratory disease. ${ }^{18} \mathrm{Al}$ though changes in smell and taste perception are known complications of a range of viral infections, these observations raise the question of whether these changes arise from secondary inflammatory processes or are due to SARS-CoV2-related dysfunction in olfactory and gustatory processing mechanisms. Of note, ACE2 is also expressed in microvillar and Bowman gland cells, ${ }^{19}$ but a direct pathogenic role for SARS-CoV-2-related olfactory epithelium damage and CNS entry has not been established. A genetic predisposition for an increased risk of COVID-19-related neurologic complications, which may be partially due to ACE2 polymorphisms linked to these conditions in previous studies, should be further investigated.

\section{Postinfectious neurologic complications}

After the acute phase of the infection, the presence and persistence of human coronaviruses within the CNS may lead to misdirected host immune responses, which could be associated with autoimmune inflammatory and demyelinating syndromes in susceptible individuals. ${ }^{9}$ In support of this hypothesis, the presence of $\mathrm{HCoV}$ RNA in the CSF of patients with acute disseminated encephalomyelitis ${ }^{20}$ and multiple sclerosis $(\mathrm{MS})^{21}$ has been reported. $\mathrm{HCoV}$ infections have also been associated with other postinfectious syndromes, including encephalitis and Guillain-Barré syndrome. ${ }^{22}$ Proposed pathogenic mechanisms include molecular mimicry between $\mathrm{HCoV}$ and myelin basic protein ${ }^{23}$ and direct invasion of leukocytes and other immune cells. ${ }^{9}$ Notably, dysregulation of the ACE2 receptor has also been implicated in the development of experimental autoimmune encephalomyelitis, a murine disease model that resembles multiple sclerosis. ${ }^{17}$

\section{Immunopathogenesis}

The structural and phylogenetic similarities between SARSCoV-2 and SARS-CoV suggest that the known pathophysiologic mechanisms for related human coronaviruses are likely applicable to SARS-CoV-2. After invasion of lung epithelium, SARS$\mathrm{CoV}$ directly infects $\mathrm{T}$ cells and macrophages, contributing to lymphopenia with reduced $\mathrm{CD} 4^{+}$and $\mathrm{CD}^{+}$cell counts and dysregulation of normal adaptive immune responses. ${ }^{4}$ Excessive 
production of proinflammatory cytokines including interleukin$1 \beta$ (IL-1 $\beta$ ), IL-6, IL-10, and tumor necrosis factor-alpha $(\mathrm{TNF}-\alpha)$, with subsequent downregulation of anti-inflammatory cytokines such as interferon gamma (IFN- $\gamma$ ), are believed to contribute to excessive inflammation and activation of proapoptotic pathways. ${ }^{24}$

In some cases, adaptive immune responses might become directed against host epitopes, resulting in postinfectious autoimmune reactions that prolong the inflammatory phase and induce tissue destruction even after the virus has been cleared. ${ }^{9}$ Data from experimental animal studies suggest that antibodies might also contribute to immunopathogenesis because increased uptake of coronavirus by macrophages can lead to macrophage activation and secretion of cytokines and other chemokines. ${ }^{4}$ In addition, coronavirus-specific $\mathrm{T}$ cells and antibodies have been shown to activate macrophages, resulting in their migration into the CNS and, ultimately, in demyelination. ${ }^{25}$

\section{Immunotherapies}

The assumption that immunocompromised patients could be at increased risk for severe disease and mortality from COVID-19, presumably because of a lack of a robust immune response, has been a matter of recent debate. A recent report by Liang et al. ${ }^{26}$ suggested that cancer patients might be at increased risk of infection and have a poorer prognosis than individuals without cancer. Conversely, it has also been suggested that immunosuppressive states may actually help blunt hyperinflammatory responses in patients with COVID-19, ${ }^{27}$ and a multicenter, randomized controlled trial of tocilizumab (IL-6 receptor blocker approved for the treatment of cytokine release syndrome) has been approved in China for patients with COVID-19 pneumonia and elevated IL-6 (ChiCTR2000029765). ${ }^{28}$ However, these assumptions are largely based on the available information from small cohorts and current evidence remains insufficient to explain an association between immunosuppressed states and the risk for COVID-19.

Nevertheless, these observations raise important questions regarding the safety of immune-modulating therapies in patients with multiple sclerosis, myasthenia gravis, and other neuroimmune disorders. In conjunction with the National Medical Advisory Committee, the National Multiple Sclerosis Society (NMSS) recently published recommendations regarding the use, continuation, and initiation of diseasemodifying therapies (DMT). ${ }^{29}$ The Association of British Neurologists $(\mathrm{ABN})$ has also published general advice related to DMT use in patients with $\mathrm{MS}^{30}$ and immunosuppressive drugs in other neuroimmunologic conditions. ${ }^{31}$ However, these recommendations are largely based on medical expertise, and more organized data are currently needed to understand the true risk of DMT use in patients with MS, keeping in mind that immunosuppression in this population presents distinct challenges that differ from other immunocompromised subtypes, including HIV and cancer, and data obtained from these cohorts may not be applicable to multiple sclerosis and other neurologic conditions.

In light of the current lack of specific treatment, the US Food and Drug Administration (FDA) recently approved the use of COVID-19 convalescent plasma in patients with severe, life-threatening disease requiring mechanical ventilation or continuous positive airway pressure, ${ }^{32}$ which has shown promising results in a small preliminary uncontrolled case series. $^{33}$ The use of this treatment modality is largely based on the premise that antibodies may be helpful in improving immune responses against SARS-CoV-2, but the potential risks of such therapies remain unknown. Novel therapies to combat the COVID-19 pandemic, including vaccines, should be designed to minimize pulmonary (and systemic) disease while optimizing an equilibrated anti-SARS-CoV-2 immune response because dysregulation of normal host immune responses could also lead to untoward consequences.

Taken together, neurotropism and neuropathogenic potential seem to be the common features of $\mathrm{HCoV}$. As the full clinical spectrum of COVID-19 continues to be described, it is quite likely that SARS-CoV-2 possesses a similar potential for extrapulmonary pathology and CNS invasion. The putative role of ACE2 in the pathophysiology of COVID-19 has recently fueled concerns regarding the use of nonsteroidal anti-inflammatory drugs, such as ibuprofen, which are known to induce the upregulation of ACE2 and, in theory, may facilitate infection with COVID$19 .^{16}$ Based on these observations, it would be reasonable to speculate that treatment with these ACE2-stimulating drugs could similarly increase the risk for severe and fatal COVID-19 from CNS complications. Owing to the paucity of current medical literature describing the neuropathogenic potential of human coronaviruses, the number of COVID-19-related neurologic complications is likely underestimated. A cross-disciplinary perspective is essential in preparing for the potential consequences of the current pandemic to human health. Awareness of the risk for acute and postinfectious neurologic complications and their contribution to COVID-19-related morbidity and mortality can help guide therapeutic decision-making and allow for the delivery of individualized treatment because the number of reported cases continues to rise.

\section{Study funding}

No targeted funding reported.

\section{Disclosure}

The author reports no disclosures relevant to the manuscript. Full disclosure form information provided by the authors is available with the full text of this article at Neurology.org/cp. 


\section{Publication history}

Received by Neurology: Clinical Practice March 31, 2020. Accepted in final form April 6, 2020.

\section{Appendix Author}

\begin{tabular}{lll}
\hline Name & Location & Contribution \\
\hline Carlos A. & University of Texas Health & $\begin{array}{l}\text { Drafting/revising the } \\
\text { Pérez, MD }\end{array}$ \\
& $\begin{array}{l}\text { Science Center at Houston, } \\
\text { Houston, TX }\end{array}$ & $\begin{array}{l}\text { manuscript, data acquisition, } \\
\text { study concept or design, and } \\
\text { analysis or interpretation of } \\
\text { data }\end{array}$ \\
\end{tabular}

\section{References}

1. World Health Organization. WHO Director-General's opening remarks at the media briefing on COVID-19-March 11, 2020.

2. Li YC, Bai WZ, Hashikawa T. The neuroinvasive potential of SARS-CoV2 may be at least partially responsible for the respiratory failure of COVID-19 patients. J Med Virol Epub 2020 Feb 27.

3. Rothan HA, Byrareddy SN. The epidemiology and pathogenesis of coronavirus disease (COVID-19) outbreak. J Autoimmun 2020;109:102433.

4. Perlman S, Dandekar AA. Immunopathogenesis of coronavirus infections: implications for SARS. Nat Rev Immunol 2005;5:917-927.

5. Chen N, Zhou M, Dong X, et al. Epidemiological and clinical characteristics of 99 cases of 2019 novel coronavirus pneumonia in Wuhan, China: a descriptive study. Lancet 2020;395:507-513.

6. Chan JFW, Kok KH, Zhu Z, et al. Genomic characterization of the 2019 novel humanpathogenic coronavirus isolated from a patient with atypical pneumonia after visiting Wuhan. Emerg Microbes Infect 2020;9:221-236.

7. Li X, Wang W, Zhao X, et al. Transmission dynamics and evolutionary history of 2019-nCoV. J Med Virol 2020;92:501-511.

8. Wang C, Liu Z, Chen Z, et al. The establishment of reference sequence for SARSCoV-2 and variation analysis. J Med Virol Epub 2020 Mar 13

9. Desforges M, Le Coupanec A, Dubeau P, et al. Human coronaviruses and other respiratory viruses: underestimated opportunistic pathogens of the central nervous system? Viruses 2019;12:14

10. Wu Z, McGoogan JM. Characteristics of and important lessons from the coronavirus disease 2019 (COVID-19) outbreak in China: summary of a report of 72314 cases from the Chinese Center for disease Control and Prevention. JAMA 2020;323: 1239-1242.

11. Zhou F, Yu T, Du R, et al. Articles Clinical course and risk factors for mortality of adult inpatients with COVID-19 in Wuhan, China: a retrospective cohort study. Lancet 2020;6736:1-9.

12. Mao L, Wang M, Chen S, et al. Neurological manifestations of hospitalized patients with COVID-19 in Wuhan, China: a retrospective case series study. medRxiv Epub $2020 \mathrm{Feb} 25$.

13. Baig AM, Khaleeq A, Ali U, Syeda H. Evidence of the COVID-19 virus targeting the CNS: tissue distribution, host-virus interaction, and proposed neurotropic mechanisms. ACS Chem Neurosci 2020;11:995-998.

14. Ding $Y, \mathrm{He} L$, Zhang $\mathrm{Q}$, et al. Organ distribution of severe acute respiratory syndrome (SARS) associated coronavirus (SARS-CoV) in SARS patients: implications for pathogenesis and virus transmission pathways. J Pathol 2004;203:622-630.
15. Netland J, Meyerholz DK, Moore S, Cassell M, Perlman S. Severe acute respiratory syndrome coronavirus infection causes neuronal death in the absence of encephalitis in mice transgenic for human ACE2. J Virol 2008;82:7264-7275.

16. Fang L, Karakiulakis G, Roth M. Are patients with hypertension and diabetes mellitus at increased risk for COVID-19 infection? Lancet Respor Med 2020;8:e21

17. Kovacs A, Ipsen A, Manzel A, Linker RA. ACE2 drives dendritic cell function and neuroantigen specific immune responses. Brain Behav Immun 2013;29:S19.

18. Giacomelli A, Pezzati L, Conti F, et al. Self-reported olfactory and taste disorders in SARS-CoV-2 patients: a cross-sectional study. Clin Infect Dis Epub 2020 March 26.

19. Brann D, Tsukahara T, Weinreb C, Logan DW, Datta SR. Non-neural expression of SARS-CoV-2 entry genes in the olfactory epithelium suggests mechanisms underlying anosmia in COVID-19 patients. bioRxiv Available at: https://www biorxiv.org/content/10.1101/2020.03.25.009084v2. Accessed April 1, 2020.

20. Yeh EA, Collins A, Cohen ME, Duffner PK, Faden H. Detection of coronavirus in the central nervous system of a child with acute disseminated encephalomyelitis. Pediatrics 2004;113:e73-e76.

21. Cristallo A, Gambaro F, Biamonti G, Ferrante P, Battaglia M, Cereda PM. Human coronavirus polyadenylated RNA sequences in cerebrospinal fluid from multiple sclerosis patients. New Microbiol 1997;20:105-114.

22. Algahtani H, Subahi A, Shirah B. Neurological complications of Middle East respiratory syndrome coronavirus: a report of two cases and review of the literature. Case Rep Neurol Med 2016;2016:3502683.

23. Chew FT, Ong SY, Hew CL. Severe acute respiratory syndrome coronavirus and viral mimicry. Lancet 2003;361:2081.

24. Prompetchara E, Ketloy C, Palaga T. Immune responses in COVID-19 and potential vaccines: lessons learned from SARS and MERS epidemic. Asian Pac J Allergy Immunol 2020;38:1-9.

25. Kim TS, Perlman S. Viral expression of CCL2 is sufficient to induce demyelination in $\mathrm{RAG}^{1 /-}$ mice infected with a neurotropic coronavirus. J Virol 2005;79:7113 LP-7120.

26. Liang W, Guan W, Chen R, et al. Cancer patients in SARS-CoV-2 infection: a nationwide analysis in China. Lancet Oncol 2020;21:335-337. Accessed April 1, 2020.

27. Mehta P, McAuley DF, Brown M, Sanchez E, Tattersall RS, Manson JJ. COVID-19: consider cytokine storm syndromes and immunosuppression. Lancet 2020;395: 1033-1034.

28. Chinese Clinical Trial Registry. A Multicenter, Randomized Controlled Trial for the Efficacy and Safety of Tocilizumab in the Treatment of New Coronavirus Pneumonia (COVID-19). 2020. Available at: chictr.org.cn/showprojen.aspx? proj=49409. Accessed April 1, 2020.

29. National Multiple Sclerosis Society. Disease Modifying Treatment Guidelines for Coronavirus (COVID-19). National Multiple Sclerosis Society; 2020. Available at: nationalmssociety.org/What-you-need-to-know-about Coronavirus- (COVID-19)/DMT-Guidelines-for-Coronavirus-(COVID-19). Accessed April 1, 2020.

30. Coles A, Lim M, Giovannone G, Anderson P. ABN Guidance on the Use of DiseaseModifying Therapies in Multiple Sclerosis in Response to the Threat of a Coronavirus Epidemic. 2020. Available at: cdn.ymaws.com/www.theabn.org/resource/collection/ 6750BAE6-4CBC-4DDB-A684-116E03BFE634/ABN_Guidance_on_DMTs_for MS_and_COVID19_APPROVED_11_March.pdf. Accessed April 1, 2020.

31. Association of British Neurologists. Association of British Neurologists Guidance on COVID-19 for People with Neurological Conditions, Their Doctors and Carers. 2020. Available at: cdn.ymaws.com/www.theabn.org/resource/collection/ 6750BAE6- 4CBC-4DDB-A684-116E03BFE634/ABN_Neurology_COVID- 19 Guidance 22.3.20.pdf.

32. U.S. Food and Drug Administration. Investigational. COVID-19 Convalescent Plasma - Emergency INDs. 2020. Available at: fda.gov/vaccines-blood- biologics/ investigational-new-drug-ind-or-device-exemption-ide-process- cber/investigationalcovid-19-convalescent-plasma-emergency-inds. Accessed April 1, 2020.

33. Shen C, Wang Z, Zhao F, et al. Treatment of 5 critically ill patients with COVID-19 with convalescent plasma. JAMA Epub 2020 March 27. 


\title{
Neurology ${ }^{\circ}$ Clinical Practice
}

\author{
Looking ahead: The risk of neurologic complications due to COVID-19 \\ Carlos A. Pérez
}

Neurol Clin Pract 2020;10;371-374 Published Online before print April 9, 2020

DOI 10.1212/CPJ.0000000000000836

This information is current as of April 9, 2020

\begin{abstract}
Updated Information \&
Services

including high resolution figures, can be found at:

http://cp.neurology.org/content/10/4/371.full.html

References

This article cites 21 articles, 1 of which you can access for free at: http://cp.neurology.org/content/10/4/371.full.html\#\#ref-list-1

Subspecialty Collections

This article, along with others on similar topics, appears in the

following collection(s):

All global neurology

http://cp.neurology.org//cgi/collection/all_global_neurology

COVID-19

http://cp.neurology.org//cgi/collection/covid_19

Public health

http://cp.neurology.org//cgi/collection/public_health

Viral infections

http://cp.neurology.org//cgi/collection/viral_infections

Permissions \& Licensing

Information about reproducing this article in parts (figures,tables) or in its entirety can be found online at:

http://cp.neurology.org/misc/about.xhtml\#permissions

Reprints

Information about ordering reprints can be found online:

http://cp.neurology.org/misc/addir.xhtml\#reprintsus
\end{abstract}

Neurol Clin Pract is an official journal of the American Academy of Neurology. Published continuously since 2011, it is now a bimonthly with 6 issues per year. Copyright ( 2020 American Academy of Neurology. All rights reserved. Print ISSN: 2163-0402. Online ISSN: 2163-0933.

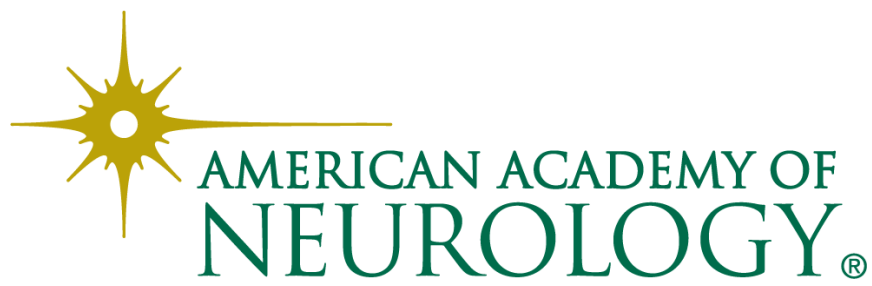

